\title{
Effect of Different Organic and Inorganic Seed Priming Method on Growth, Yield and Quality Parameters of Field Pea (Pisum sativum L.)
}

\author{
G. Abdul Wajid ${ }^{1}$, KalneniJahnavi ${ }^{1}$, Arun Kumar Chaurasia ${ }^{1}$, \\ N. Bharath Reddy ${ }^{1}$ and B. Prudvi Raj Naidu ${ }^{2}$
}

\author{
${ }^{I}$ Department of Genetics and Plant Breeding, Naini Agricultural Institute, Sam Higginbottom \\ University of Agriculture, Technology and Sciences, Prayagraj, U. P., India \\ ${ }^{2}$ State Institute for Management of Agriculture, Department of Agriculture, \\ Govt. of. Uttar Pradesh, India \\ *Corresponding author
}

\section{A B S T R A C T}

\section{Keywords}

Field pea, $\mathrm{GA}_{3}$, PEG 6000, $\mathrm{KNO}_{3}$, $\mathrm{CaCl}_{2}, \mathrm{KH}_{2} \mathrm{PO}_{4}$, Aloe Vera extract, Curry leaf extract, Ginger extract, Moringa leaf extract, Tulasi leaf extract, Priming, Germination, CRD

\section{Article Info}

\section{Accepted:} 04 December 2020 Available Online: 10 January 2021
Pulses are referred to as poor man's meat, as they are major sources of protein and compliment the stable cereals in the diet with essential nutrients. Field pea is an annual cool season grain legume or pulse crop and majorly grown in rabi season and third most popular rabi pulse of India after chickpea and lentil. The study was conducted to determine the "Effect of different organic and inorganic seed priming method on growth, yield and quality parameters of field pea (Pisum sativum L.)" The experiment was carried out at Field Experimentation Centre and Seed Testing Laboratory of the Department of Genetics and Plant Breeding, Sam Higginbottom University of Agriculture, Technology \& Sciences, Prayagraj (UP) during Rabi-2019. The experiment was laid out in Randomized Blocked Design for field studiesand Completely Randomized design for lab studies and comprised of 13 treatments and 3 replications. The treatments were $\mathrm{T}_{0}(\mathrm{Control}), \mathrm{T}_{1}($ Distilled water), $\mathrm{T}_{2}$ (Tulasi leaf extract@ 5\%), $\mathrm{T}_{3}$ (Pongamia Leaf Extract@ 5\%), $\mathrm{T}_{4}($ Curry Leaf Extract@5\%), $\quad \mathrm{T}_{5}$ (Moringa Leaf Extract@5\%), $\mathrm{T}_{6}$ (Neem Leaf Extract @ 5\%), $\mathrm{T}_{7}(\mathrm{KH} 2 \mathrm{PO} 4 @ 1 \%), \mathrm{T}_{8}(\mathrm{KH} 2 \mathrm{PO} 4 @ 3 \%), \mathrm{T}_{9}(\mathrm{KN} 03 @ 1 \%) \mathrm{T}_{10}(\mathrm{KN} 03 @ 3 \%), \mathrm{T}_{11}\left(\mathrm{GA}_{3}\right.$ $100 \mathrm{ppm}), \mathrm{T}_{12}$ (PEG $\left.6000 @ 20 \%\right)$ with a soaking duration of 12 hours. The results revealed that seeds primed with $\mathrm{T}_{10}(\mathrm{KN} 03$ @ 3\%) improved Germination\%, Growth, yield and Seed quality Parameters followed by $\mathrm{T}_{6}$ (Neem Leaf Extract @ 5\%) and the least performance was observed in $\mathrm{T}_{0}$ (control) when compared with other treatments. Hence, seed priming with $\left(\mathrm{KNO}_{3} @ 3 \%\right)$ and Neem Leaf Extract @5\% could be recommended for field pea as a pre-sowing seed treatment.

\section{Introduction}

Pulses are referred to as poor man's meat, as they are major sources of protein and compliment the stable cereals in the diet with essential nutrients. They occupy pivotal position particularly in developing countries like India, where most of the population is vegetarian. Pulses belong to the family Leguminosae and subfamily Papilionoidaceae. They provide 22-24 per cent protein and the seeds are considered 
easily digestible and the increasing demand of protein rich raw material for animal feed or intermediary product for human nutrition, there is raising interest in these crops as a protein source (Santalla et al., 2001).

Field pea (Pisum sativum L.) is represented as one of the world's most seasoned cultivated crop, before tenth and ninth centuries BC (Zohary, Hopf, 2000). Pisum sativum comprises of both the wild species (P.fulvum and P.eratius) and developed species ( $P$. abyssinicum) started from the Mediterranean locale, principally in the Middle East (Ellis et al., 2011). The crop is cultivated in numerous nations and right now India's position is fourth among the pulse production in the world with cultivated area of 6.33 million ha. (Source: Devi et al., 2017).

Field pea (Pisum sativum L.) is a temperate crop grown in higher altitudes in tropical areas with temperature ranging between 7 $30^{\circ} \mathrm{C}$. It is diploid with $2 \mathrm{n}=14$, It is one of the sixth major pulse crops cultivated globally and is second highest yielding grain legume next to broad bean (Vicia faba). Field pea (Pisum sativum L.) is a self-pollinated rabi pulse crop which is developed for nourishment, feed and vegetables.

In India, Total pulse production is $25.23 \mathrm{M}$ tonnes (2017-18) total area under pea production is 9.01 lakh ha and total production of 8.49 lakh tons were recorded. In India Uttar Pradesh ranked first both in area and production (37.90\% and 41.58\%) followed by Madhya Pradesh $(38.67 \%$ and $32.98 \%)$ and Jharkhand $(3.80 \%$ and $4.85 \%)$. In case of productivity Rajasthan holds first rank (1867 kg/ha) followed by Punjab (1297 $\mathrm{kg} / \mathrm{ha}$ ) and Jharkhand (1203 kg/ha). The lowest production was observed in Maharashtra $(390 \mathrm{~kg} / \mathrm{ha})$ followed by Chhattisgarh (437 kg/ha). (Source: Annual statistical report2016-17).
Nutritional value for 100 g. includes energy81 Kcal, Carbohydrates -14.45 g, Protein$5.42 \mathrm{~g}$, Total fat- $0.40 \mathrm{~g}$, Dietary fiber- $5.1 \mathrm{~g}$, Cholesterol - $0 \mathrm{mg}$ (Source: USDA National Nutrient data base)

Supply of good quality seeds is an important crucial point and it becomes imperative to evolve a strategy to produce quality seeds and made them available in time at a reasonable price to the farming community. Quality seed is the key for successful agriculture which demands that each and every seed should be ready to germinate and produce a vigorous seedling ensuring higher yield (Ananthi et al., 2015). Annual loses due to deterioration can be as much as $25 \%$ of the harvested pulses crop. It is one of the basic reasons for low productivity (Shelar, 2008).

Seed invigoration techniques are used to enhance germination and vigor of seed and seedling growth. It includes the pre-soaking of seeds that improves seed performance by rapid and uniform germination, normal and vigorous seedlings, which result in faster and higher rate of germination and emergence in different crops (Farooq et al., 2007), which also helps seedlings to grow in biotic or abiotic stress condition (Ashraf and Foolad, 2005).

The benefits of priming are it decreases the time to germination. Increases the germination rate. Helps in uniform and faster emergence. Helps the crops in competing with weeds more effectively. Reduces the amount of seed borne fungi (Basra et al., 2004).

\section{Materials and Methods}

The experimental study was carried out at Field Experimentation Centre and Seed Testing Laboratory of the Department of Genetics and Plant Breeding, Sam Higginbottom University of Agriculture, 
Technology \& Sciences, Prayagraj (UP) during Rabi-2019.

The field experiment was conducted in Randomized block design (R.B.D) with three replications and the variety used in this experiment was IP. The data was collected on five randomly selected plants from each plot and measurement of different observations was recorded.

The lab experiment was conducted in Completley Randomised Design (C.R.D) with four replications and the variety used in this experiment was IP-. The data was collected on ten randomly selected healthy seedlings from each replication and measurement of different observations was recorded.

The treatments were $\mathrm{T}_{0}$ (Control), $\mathrm{T}_{1}$ (Distilled water), $\mathrm{T}_{2}$ (Tulasi leaf extract @ 5\%), $\mathrm{T}_{3}$ (Pongamia Leaf Extract@ 5\%), $\mathrm{T}_{4}$ (Curry Leaf Extract @ 5\%), $\mathrm{T}_{5}$ (Moringa Leaf Extract @ 5\%), $\mathrm{T}_{6}$ (Neem Leaf Extract @ $5 \%), \mathrm{T}_{7}(\mathrm{KH} 2 \mathrm{PO} 4 @ 1 \%), \mathrm{T}_{8}(\mathrm{KH} 2 \mathrm{PO} 4 @$ $3 \%), \mathrm{T}_{9}\left(\mathrm{KN} 03\right.$ @ 1\%) $\mathrm{T}_{10}\left(\mathrm{KN} 03\right.$ @ 3\%), $\mathrm{T}_{11}$ $\left(\mathrm{GA}_{3}\right.$ 100ppm), $\mathrm{T}_{12}$ (PEG 6000 @ 20\%) with a soaking duration of 12 hours

\begin{tabular}{|c|c|c|}
\hline $\begin{array}{c}\text { Priming } \\
\text { Methods }\end{array}$ & $\begin{array}{c}\text { Treatment } \\
\text { Symbol }\end{array}$ & Treatments \\
\hline $\mathbf{T}_{\mathbf{0}}$ & Control & Unprimed seeds \\
\hline $\mathbf{T}_{\mathbf{1}}$ & Distilled Water & Hydro priming \\
\hline $\mathbf{T}_{\mathbf{2}}$ & Tulasileaf extract $(5 \%)$ & Organic priming \\
\hline $\mathbf{T}_{\mathbf{3}}$ & Pongamialefextract(5\%) & Organic priming \\
\hline $\mathbf{T}_{\mathbf{4}}$ & Curry leaf extract $(5 \%)$ & Organic priming \\
\hline $\mathbf{T}_{\mathbf{5}}$ & Moringaleaf extract $(5 \%)$ & Organic priming \\
\hline $\mathbf{T}_{\mathbf{6}}$ & Neemleaf extract $(5 \%)$ & Organic priming \\
\hline $\mathbf{T}_{\mathbf{7}}$ & $\mathrm{KH} 2 \mathrm{PO} 4(1 \%)$ & Halo priming \\
\hline $\mathbf{T}_{\mathbf{8}}$ & $\mathrm{KH} 2 \mathrm{PO} 4(3 \%)$ & Halo priming \\
\hline $\mathbf{T}_{\mathbf{9}}$ & $\mathrm{KNO3}(1 \%)$ & Halo priming \\
\hline $\mathbf{T}_{10}$ & $\mathrm{KNO}(3 \%)$ & Halo priming \\
\hline $\mathbf{T}_{11}$ & $\mathrm{GA3}(100 \mathrm{ppm})$ & Harmonal priming \\
\hline $\mathbf{T}_{12}$ & PEG 6000 (5\%) & Osmo priming \\
\hline
\end{tabular}

\section{Preparation of solutions}

For preparation of solution, the required chemicals have been collected from Department of Genetics and Plant Breeding, Prayagraj and fresh leaves for organic priming were collected from Department of Horticulture Research Fields, SHUATS.

For the preparation of solutions of botanicals, fresh leaves (Tulasi, Pongamia, Curryleaf, Moringa, Neem) were shade dried and ground into fine powder. To make $5 \%$ solution, $5 \mathrm{gm}$ of each leaf powder was added to $100 \mathrm{ml}$ of distilled water in separate beakers.
For the preparation of $1 \%$ solution of $\mathrm{KH}_{2} \mathrm{PO}_{4}, \mathrm{KNO}_{3} 1 \mathrm{gm}$ of each salt was dissolved in distilled water to make the volume up to $100 \mathrm{ml}$. For the preparation of $3 \%$ solution of $\mathrm{KH}_{2} \mathrm{PO}_{4}, \mathrm{KNO}_{3} 3 \mathrm{gm}$ of each was dissolved in distilled water to make the volume up to $100 \mathrm{ml}$. For the preparation of 100 ppm GA3 solution, 100mg of GA3 was dissolved in $1000 \mathrm{ml}$ distilled water. For the preparation of $20 \%$ solution of PEG 6000, 20 $\mathrm{g}$ of PEG 6000 was dissolved in distilled water to make the volume up to $100 \mathrm{ml}$.

After preparing all the above solutions, seeds of field pea were added to each of the prepared solution and soaked for about $12 \mathrm{hr}$ 
at $25^{\circ} \mathrm{C}$ temperature. Untreated seed is known as control. After $12 \mathrm{hr}$ of soaking, the solution was drained out from the beaker and presoaked seeds were air dried at room temperature to original weight and then placed for sowing and germination in the laboratory under controlled condition.

\section{Results and Discussion}

It is evident from the present investigation that priming treatments has significant effect on quality parameters in fenugreek. In general, most of the treatments have increased growth, yield, quality parameters as compared to control (untreated seeds). In terms of field parameters like Field emergence (\%), Plant height $(\mathrm{cm})$, Days to 50\% flowering, Number of pods per plant, Number of seeds per pod, biological yield $(\mathrm{g})$, seed yield per plot $(\mathrm{g})$, Harvest index the treatment $\mathrm{T}_{10}-\mathrm{KNO}_{3} @$ 3\% (Halopriming) recorded as highest followed by $\mathrm{T}_{6}$ - Neem extract @ 5\% (Organic priming), $\mathrm{T}_{2}$-Distilled water(Hydro priming).

Saed-Moochesi et al., (2014) also found similar results in the maize seed $\mathrm{KNO}_{3}$ and urea priming lead to high activities of antioxidant defensive enzymes and increase the tolerance level to abiotic stresses such as salt and drought which increased the emergence rate (Table 1 and 2).

Table.1 Mean performance of growth and yield parameters in field pea

\begin{tabular}{|c|c|c|c|c|c|c|c|c|c|c|}
\hline S.No & Treatments & $\begin{array}{c}\text { Field } \\
\text { emergence } \\
(\%)\end{array}$ & $\begin{array}{c}\text { Plant } \\
\text { height } \\
(\mathrm{cm})\end{array}$ & $\begin{array}{c}\text { No of } \\
\text { Branches }\end{array}$ & $\begin{array}{c}\text { Days to } \\
50 \% \\
\text { flowering }\end{array}$ & $\begin{array}{l}\text { No. of } \\
\text { pods per } \\
\text { plant }\end{array}$ & $\begin{array}{c}\text { No. of } \\
\text { seeds } \\
\text { per pod }\end{array}$ & $\begin{array}{c}\text { Seed } \\
\text { yield per } \\
\text { plot }\end{array}$ & $\begin{array}{l}\text { Biological } \\
\text { yield }\end{array}$ & $\begin{array}{l}\text { Harvest } \\
\text { Index }\end{array}$ \\
\hline 1 & $\mathbf{T}_{\mathbf{0}}$ & 76.333 & 77.053 & 7.333 & 55.600 & 8.833 & 3.313 & 242.690 & 357.263 & 0.679 \\
\hline 2 & $\mathbf{T}_{1}$ & 86.867 & 89.667 & 9.333 & 49.600 & 12.733 & 3.660 & 527.940 & 651.830 & 0.810 \\
\hline 3 & $\mathbf{T}_{2}$ & 86.637 & 81.007 & 9.000 & 50.133 & 10.467 & 3.500 & 417.110 & 538.060 & 0.772 \\
\hline 4 & $\mathbf{T}_{3}$ & 79.833 & 83.720 & 9.333 & 58.000 & 10.400 & 3.347 & 488.863 & 604.697 & 0.792 \\
\hline 5 & $\mathbf{T}_{4}$ & 78.167 & 83.200 & 9.667 & 52.200 & 9.767 & 3.460 & 436.323 & 562.650 & 0.775 \\
\hline 6 & $\mathbf{T}_{5}$ & 83.237 & 85.993 & 9.000 & 51.000 & 12.000 & 3.620 & 348.073 & 473.200 & 0.734 \\
\hline 7 & $T_{6}$ & 89.523 & 90.733 & 10.667 & 49.000 & 12.833 & 3.767 & 554.463 & 685.063 & 0.809 \\
\hline 8 & $\mathbf{T}_{7}$ & 82.377 & 80.827 & 8.667 & 57.467 & 10.667 & 3.553 & 347.233 & 467.567 & 0.739 \\
\hline 9 & $\mathbf{T}_{8}$ & 84.757 & 82.770 & 10.333 & 51.400 & 9.667 & 3.523 & 442.160 & 555.503 & 0.782 \\
\hline 10 & $\mathbf{T}_{9}$ & 78.080 & 82.093 & 8.667 & 54.667 & 9.667 & 3.470 & 394.593 & 499.653 & 0.774 \\
\hline 11 & $T_{10}$ & 92.373 & 92.383 & 11.333 & 47.833 & 13.367 & 4.000 & 625.913 & 732.080 & 0.855 \\
\hline 12 & $\mathbf{T}_{11}$ & 89.033 & 130.433 & 9.667 & 61.733 & 9.000 & 3.733 & 181.933 & 301.850 & 0.601 \\
\hline 13 & $\mathrm{~T}_{12}$ & 78.000 & 86.070 & 10.000 & 52.800 & 10.100 & 3.447 & 366.783 & 490.473 & 0.741 \\
\hline \multicolumn{2}{|c|}{ Grand mean } & 83.47821 & 88.15205 & 9.461538 & 53.18718 & 10.73077 & 3.568718 & 413.3908 & 532.2992 & 0.758597 \\
\hline \multicolumn{2}{|r|}{ C.D. } & 2.742 & 1.610 & 0.59 & 1.772 & 0.655 & 0.226 & 163.221 & 165.163 & 0.069 \\
\hline \multicolumn{2}{|r|}{ SE(m) } & 0.934 & 0.548 & 0.715 & 0.603 & 0.223 & 0.077 & 55.590 & 56.251 & 0.023 \\
\hline \multicolumn{2}{|r|}{$\operatorname{SE}(d)$} & 1.321 & 0.775 & 1.011 & 0.853 & 0.316 & 0.109 & 78.616 & 79.551 & 0.033 \\
\hline \multicolumn{2}{|r|}{ C.V. } & 1.938 & 1.077 & 13.091 & 1.965 & 3.602 & 3.738 & 23.291 & 18.304 & 5.353 \\
\hline
\end{tabular}


Table.2 Mean performance of seed quality parameters in field pea

\begin{tabular}{|c|c|c|c|c|c|c|c|c|c|}
\hline Treatments & $\begin{array}{c}\text { Germination } \\
\%\end{array}$ & $\begin{array}{l}\text { Root length } \\
\text { (cm) }\end{array}$ & $\begin{array}{l}\text { Shoot length } \\
\text { (cm) }\end{array}$ & $\begin{array}{l}\text { Seedling } \\
\text { length } \\
(\mathrm{cm})\end{array}$ & $\begin{array}{c}\text { Seedling } \\
\text { fresh } \\
\text { weight }\end{array}$ & $\begin{array}{c}\text { Seedling } \\
\text { dry weight } \\
\text { (mg) }\end{array}$ & $\begin{array}{l}\text { Vigour } \\
\text { index-I }\end{array}$ & $\begin{array}{l}\text { Vigour } \\
\text { index-II }\end{array}$ & Seed Index \\
\hline T0 & 80.000 & 6.750 & 18.000 & 24.750 & 2.725 & 1.300 & $1,979.200$ & 103.875 & 22.060 \\
\hline T1 & 92.750 & 8.325 & 22.500 & 30.825 & 3.800 & 1.738 & $2,859.050$ & 161.150 & 24.020 \\
\hline $\mathbf{T} 2$ & 91.000 & 7.875 & 22.125 & 30.000 & 3.700 & 1.625 & $2,730.300$ & 147.913 & 22.797 \\
\hline T3 & 88.750 & 7.250 & 20.750 & 28.000 & 3.550 & 1.475 & $2,485.275$ & 130.875 & 22.387 \\
\hline $\mathbf{T 4}$ & 86.500 & 7.175 & 19.925 & 27.100 & 3.475 & 1.388 & $2,343.475$ & 120.013 & 23.147 \\
\hline T5 & 90.500 & 8.600 & 22.375 & 30.975 & 3.550 & 1.700 & $2,802.750$ & 153.813 & 23.893 \\
\hline T6 & 93.750 & 8.750 & 22.875 & 31.625 & 4.225 & 1.888 & $2,965.650$ & 177.013 & 25.180 \\
\hline T7 & 88.750 & 7.800 & 20.250 & 28.050 & 3.475 & 1.470 & $2,489.250$ & 130.495 & 23.443 \\
\hline T8 & 91.250 & 7.700 & 21.825 & 29.525 & 3.750 & 1.590 & $2,693.850$ & 145.025 & 23.313 \\
\hline T9 & 91.000 & 8.025 & 21.750 & 29.775 & 3.975 & 1.650 & $2,708.900$ & 150.225 & 23.820 \\
\hline T10 & 96.000 & 9.000 & 24.375 & 33.375 & 4.550 & 2.188 & $3,203.975$ & 209.975 & 26.503 \\
\hline T11 & 92.250 & 7.800 & 28.000 & 35.800 & 3.275 & 1.525 & $3,302.050$ & 140.700 & 24.250 \\
\hline T12 & 90.250 & 7.575 & 21.350 & 28.925 & 3.250 & 1.638 & $2,610.850$ & 147.850 & 23.370 \\
\hline Grand mean & 90.211 & 7.894 & 22.00 & 29.901 & 3.638 & 1.620 & 2705.73 & 147.60 & 23.70641 \\
\hline C.D. & 1.646 & 0.251 & 1.477 & 1.494 & 0.220 & 0.130 & 138.652 & 12.169 & 1.207 \\
\hline SE(m) & 0.573 & 0.087 & 0.515 & 0.520 & 0.077 & 0.045 & 48.289 & 4.238 & 0.411 \\
\hline $\operatorname{SE}(d)$ & 0.811 & 0.123 & 0.728 & 0.736 & 0.108 & 0.064 & 68.290 & 5.994 & 0.582 \\
\hline C.V. & 1.271 & 2.210 & 4.676 & 3.479 & 4.210 & 5.559 & 3.569 & 5.742 & 3.004 \\
\hline
\end{tabular}


Seed yield per plot is high in treatment combination of $\mathrm{KNO}_{3}$ is due to the potassium $(\mathrm{K})$ it is associated with the movement of water, nutrients and carbohydrates in plant tissues.

In terms of lab parameters like Germination $(\%)$, Root length $(\mathrm{cm})$, Shoot length $(\mathrm{cm})$, Seedling length $(\mathrm{cm})$, Seedling fresh weight (g), Seedling dry weight (g), Vigour index I, Vigour index II the treatment $\mathrm{T}_{10}-\mathrm{KNO}_{3} @$ 3\% (Halopriming) recorded maximum values, followed by $\mathrm{T}_{6}$ - Neem leaf extract @5\% (Organic priming), $\mathrm{T}_{11}$-GA3 @ 100ppm (Hormonal priming).

Muhammad Amjad et al., (2007), also found similar results by priming seeds with distilled water (hydro priming) and salts (halo priming) and observed that seeds treated with $\mathrm{KNO}_{3}(3 \%)$ showed increase of seed germination over control and all other treatments.

Mohammad Armin et al., (2010) investigated the effect of seed priming on germination and seedling growth of watermelon, and found that $\mathrm{KNO}_{3}$ had the most effective impact on emergence and seedling growth. Compared with the non-primed seeds, seed priming with $\mathrm{KNO}_{3}$ increased the germination by $17.87 \%$.

On the basis of results obtained from the present investigation, it is concluded that seed priming improves germination, vigour, growth and yield parameters of field pea. Treated seeds performed better than untreated seeds(control). Of all the treatments, seed priming with $\mathrm{T}_{10}-\mathrm{KNO} 3(3 \%)$ (Halo priming) recorded best results, followed by $\mathrm{T}_{6}$-Neem leaf extract $(5 \%)$ (Organic priming) and $\mathrm{T}_{1}$ Distilled water(Hydro priming) for field parameters and seed priming with KNO3 (3\%)(Halo priming) recorded best results, followed by $\mathrm{T}_{6}$-Neem leaf extract (5\%)(Organic priming) and $\mathrm{T}_{11^{-}}$
GA3(100ppm) (Hormonal priming) for quality parameters.

\section{References}

Afzal, I., S.M.A. Basra, N. Ahmad and M. Farooq. (2005). Optimization of hormonal priming techniques for alleviation of salinity stress in wheat (Triticum aestivum L.). Caderno de Pesquisa Série Biologia, 17: 95-109.

Anonymous. 1983. Association of Official Seed Analysis (AOSA). Seed vigor testing handbook. Contribution No. 32 to the handbook on seed testing.

Armin, M., Asgharipour, M., \&RazaviOmrani, M. (2010). The effect of seed priming on germination and seedling growth of watermelon (Citrullus lanatus). Advances in Environmental Biology, 4(3), 501-505.

Chavan, N. G., Bhujbal, G. B., \&Manjare, M. R. (2014).Effect of seed priming on field performance and seed yield of soybean [Glycine max (L.)Merill] varieties. The Bioscan, 9(1), 111-114

Gunasekar, J., Kamaraj, A., \&Padmavathi, S. (2017).Effect of botanical seed priming on seed quality characters in blackgram [Vigna mungo (1.) Hepper] cv. CO6. Plant Archives, 17(2), 13831387.

Hamidi, R., Pirasteh-Anosheh, H., \&Izadi, M. (2013). Effect of seed halo-priming compared with hydro-priming on wheat germination and growth. International Journal of Agronomy and Plant Production, 4(7), 1611-1615.

Saed-Moocheshi, A., Shekoofa, A., Sadeghi, H., and Pessarakli, M. (2014). Drought and salt stress mitigation by seed priming with $\mathrm{KNO}_{3}$ and urea in various maize hybrids: an experimental approach based on enhancing antioxidant responses. Journal of plant 
nutrition, 37(5), 674-689.

Sajjan, A. S., Dhanelappagol, M. S., and Jolli, R. B. (2017). Seed quality enhancement through seed priming in pigeonpea [Cajanus cajan (L.) Millsp.]. Legume Research-An International Journal, 40(1), 173-177.

Santalla, M., Amurrio, J. M., and De Ron, A. M. (2001).Food and feed potential breeding value of green, dry and vegetable pea germplasm. Canadian Journal of plant science, 81(4), 601610.

Sharma, A. D., Rathore, S. V. S., Srinivasan, K., and Tyagi, R. K. (2014). Comparison of various seed priming methods for seed germination, seedling vigour and fruit yield in okra (Abelmoschus esculentus L. Moench). Scientia Horticulturae, 165, 75-81.

Shehzad, M., Ayub, M., Ahmad, A. U. H., and Yaseen, M. (2012). Influence of priming techniques on emergence and seedling growth of forage sorghum (Sorghum bicolor L.). J Anim Plant Sci, 22(1), 154-158.

Zohary D. and Hopf M. (2000). Domestication of Plants in the Old World.3 rd edition. Oxford University Press. Pp. 316.

\section{How to cite this article:}

Abdul Wajid, G., Kalneni Jahnavi, Arun Kumar Chaurasia, N. Bharath Reddy and Prudvi Raj Naidu, B. 2021. Effect of Different Organic and Inorganic Seed Priming Method on Growth, Yield and Quality Parameters of Field Pea (Pisum sativum L.). Int.J.Curr.Microbiol.App.Sci. 10(01): 280-286. doi: https://doi.org/10.20546/ijcmas.2021.1001.034 